\title{
A front row seat: Štefan Schwarz and the Smolenice meeting
}

\section{Paul S. Mostert ${ }^{1}$}

Received: 21 March 2019 / Accepted: 25 August 2019 / Published online: 26 September 2019 (c) Springer Science+Business Media, LLC, part of Springer Nature 2019

The middle of the twentieth century witnessed some of the most extraordinary upheavals experienced by the world in its history. ŠTEFAN SCHWARZ had a frontrow seat to it all. Sometimes that front-row seat was hardly the best seat. In particular, he witnessed the Holocaust from an all too close front row seat as a survivor of two of Nazi Germany's most notorious concentration camps where no more than one in two managed to survive. He was able to survive and advance through the dark postwar period of Soviet hegemony in Czechoslovakia. In the 1960s, Bratislava, where SCHWARz lived and worked, sat at the gates of the Iron Curtain. As President of the Slovak Academy of Sciences and Vice President of the Czechoslovakian Academy of Sciences, SchWARZ was more-or-less a Gate-Keeper for East-West scientific communication flow in mathematics-particularly for that in semigroup theory: indeed, he had a front-row seat. His efforts may have been facilitated by taking advantage of connections with Alexander Dubček, whose political career had Slovakian roots.

It was in the short period from Spring, 1967 through Spring, 1968 that he made what is, perhaps, his greatest and most enduring contribution to the mathematics community: his planning and organization of the First International Symposium on Semigroups in June of 1968 and its enduring legacy, Semigroup Forum. Just 2 months later, the invasion of Czechoslovakia by the Soviet Union and its allies ended the Prague Spring and the reign of his friend, Dubček. SCHWARZ was able to survive the aftermath of that invasion, though apparently not without some costs, which I will discuss later.

In the 1966 International Congress of Mathematicians, held in Moscow during August of that year, SCHWARZ met with ALFRED H. CLIFFORD from Tulane University in the United States, and JEVGENIJ S. LJAPIN from A. I. Herzen Leningrad State Teacher Training College in the Soviet Union. It was then that the idea for the international symposium was first broached and discussed. While I cannot say with certainty

Communicated by Jimmie D. Lawson.

Paul S. Mostert-Emeritus Professor at the University of Kansas.

$凶 \quad$ Paul S. Mostert

psmostert@ku.edu

1690 Mason Headley Rd., \#324, Lexington, KY 40504, USA 
which of the three first uttered the words that brought the idea into their discussions, there is no question but that SCHWARZ had a front-row seat in both the initiation of the idea and the execution of the plan for the First International Symposium on Semigroups.

In the early 1960s efforts among mathematicians were being made to encourage more contact across the Iron Curtain. Governments from both sides were, though cautious, more amenable. My records show that we had visitors to the Mathematics Department at Tulane University from East-bloc countries Poland, Czechoslovakia, and Hungary at least by 1964, some costs for which were supported in part by the U.S. Office of Naval Research.

Nevertheless prior to the 1966 World Congress of Mathematics in Moscow, there had been depressingly little intercourse between the eastern-bloc mathematicians and those in the western bloc. Mathematicians in the Soviet Union were required to write their papers and present their lectures in the Russian language. (This perhaps does not seem quite so severe, when one remembers that English was not the widely accepted language for scientific writing and presentation that it is today.) With few exceptions, western mathematicians were illiterate in the language (CLIFFORD being one of the exceptions) and of those who were not, few, including CLIFFORD, had the facility to be able to follow a lecture in the language. These restrictions were slightly relaxed at the 1966 World Congress to allow summaries in another language to be made by Soviet mathematicians.

The 1968 First International Symposium on Semigroups at Smolenice was one of a very few efforts in the sixties that brought together the leading experts worldwide in a single subject, including those from the USSR, for intimate discussions of the status of the subject and its needs for the future to benefit all those working in the subject area, regardless of the accident of their birth on one or the other side of the Iron Curtain. The Symposium was a singular and bold undertaking masterfully accomplished. It was primarily the work of one ŠTEFAN SCHWARZ.

KARL H. HOFMANN and I first met SCHWARZ in 1961 during a motor trip through Czechoslovakia. Early in March of 1967, after we had sent him a copy of our 1966 book, Elements of Compact Semigroups [4], we received a hand-written letter from him in which he mentioned his discussions with CLIFFORD and LJAPIN the previous year and his efforts to organize the meeting that the three had discussed at the 1966 International Congress.

Then in April, he again wrote to HoFMANN and me jointly and to CLIFFORD separately inviting the three of us to the proposed meeting and to present one-hour lectures there. He also asked for suggestions for others to invite and to give one-hour lectures as well as the themes to emphasize. We responded with a joint letter from the three of us giving a number of suggestions and a list of 31 people active in the algebraic area and 19 in the topological area of semigroups who might be invited to participate. A little over half of those suggested actually were able to attend the Symposium the following year.

Plans called for several 1-h (actually, 50-min) lectures and a larger number of 30min lectures. Abstracts of lectures and any number of Short Communications were to be sent in time to be distributed to the attendees via mimeographed copy. By the time of the actual meetings, the longer lectures had been reduced to $45 \mathrm{~min}$. The speakers were 


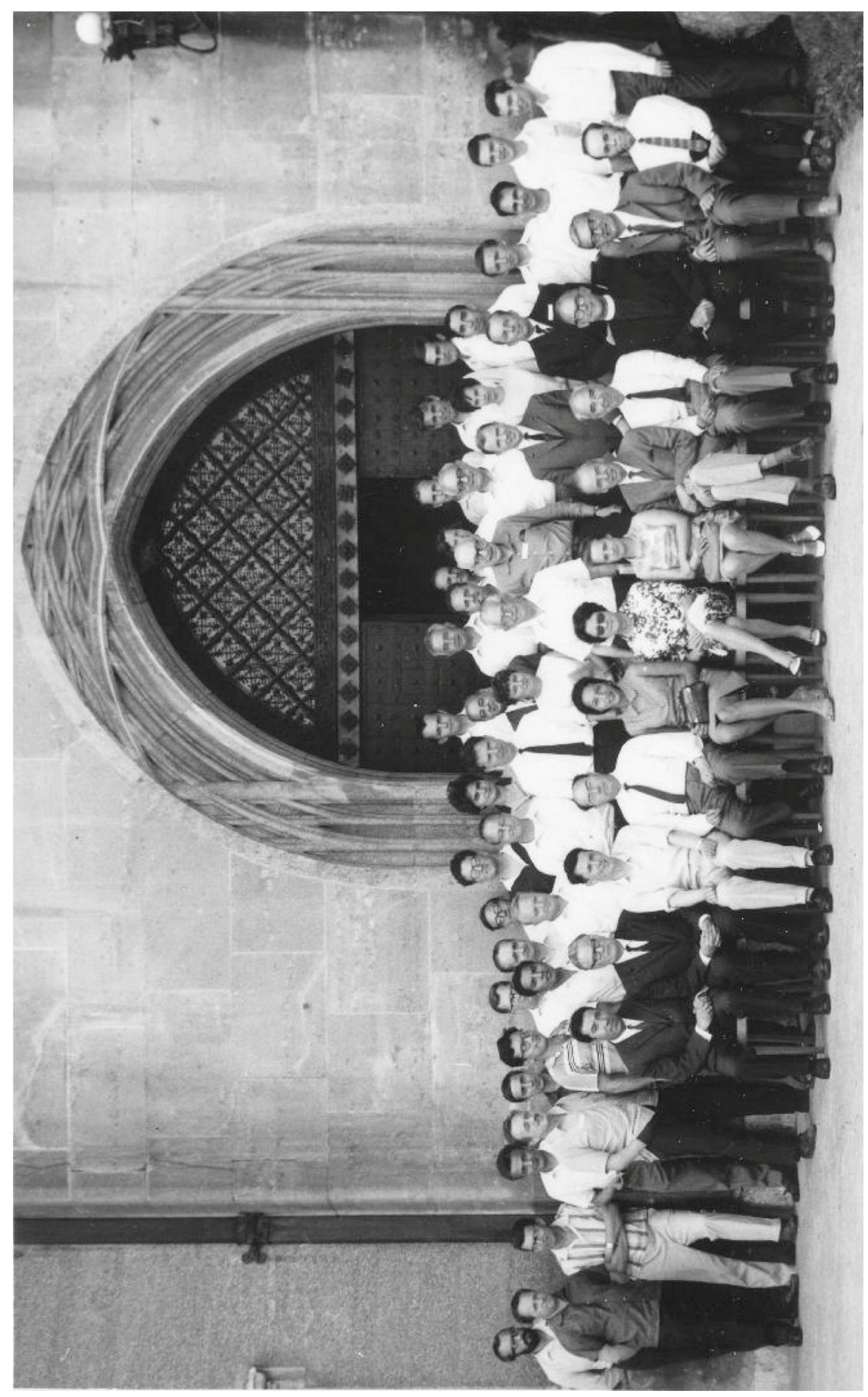


A.H. Clifford, P. Dubreil, K.H. Hofmann \& P.S. Mostert, E.S. Ljapin, W.D. MunN, L. RÉDEI, V.V. WAGNER and Š. SCHWARZ. J. RHODES was originally scheduled to give a 45-min lecture, but was unable to attend.

Thirty-minute lectures were presented by K. CulíK, L. M. Gluskin, P. GoralCík \& J. Sichler, H.J. Hoehnke, J.M. Howie, G. Lallement, B.M. Schein, L. Schmetterer, L.N. Shevrin, and L.B. Shneperman, while T. TAmura. E.A. BEHRENS and M.M. LESOKHIN were scheduled to give 30-min lectures, but were unable to attend as planned. SCHEIN actually delivered a longer address at the request of SCHWARZ. Besides this, the program also included 24 communications which were not delivered as talks. The authors of these communications were: J. CALAIS, A.H. Clifford and J. Dénes, M. Dubreil- Jacotin, I. Fabrici, Z. Hedrlín, Kh. Inasaridze, K. Keimel, S. Lajos, L. Lesieur, H. Lugowski, A. A. Markov, D. Miller, M. Nivat, A. PaAlman- de Miranda, M. Petrich, Gy. Pollák and L. Megyesi, B. Pondelícek, V.N. Saliu, O. Steinfeld, G. Szász, R. Šulka, E.G. Šutov, T. TAmurA, G. THIERRIN. Unfortunately, SchwARZ was unable to write the expected report of the Symposium or to publish the manuscripts he received in the Slovak Academy of Sciences Matematický Časopis as he had intended. Two short reports about the meeting were published, one in Slovak by BOSÁK in Matematický Casopis [1] and the other in Russian by LJAPIN and SHEVRIN in Uspekhi Mat. Nauk [2]. Neither of these was able to give an accurate list of the attendees or, indeed, of the lectures actually presented or even a dependably accurate number of those who actually attended. Each tried to give the number of attendees according to nationality, but failed to agree with one another and with the facts. National identity, where unsure by members of the Organizing Committee, appeared to be based more on the country of residence at the time of last communication with the Organizing Committee for many of the attendees. The fact that the citizenship of a number of attendees was misidentified is testimony to the degree of international exchange of mathematicians already in progress at the time. The fact that SCHWARZ neither published a report nor managed to publish the submitted manuscripts as he had intended is certainly not characteristic of him and would appear to be a likely consequence of the invasion of Czechoslovakia by the Soviet Union and its allies just two months after the Symposium was over.

A conference group picture of 49 of the attendees has survived. That picture was printed in the report of the meeting by BOSÁK and it appeared in Semigroup Forum in a later article article by HOFMANN [3]. I have, with a great deal of help from semigroupers everywhere, been able to identify all of those in the picture, as well as ten who attended but were not in the picture. These were JOZZSEF DÉNES, Hungary, KAREL Drbohlav, Czechoslovakia, HANS JURGEN HOEHNKE and two of his Ph.D. students HeINRICH SEIDEL and WolfGang WeChleR, German Democratic Republic, SÁNDOR LAJOS, Hungary, HeRBERT LugOwsKi, German Democratic Republic, ISTVÁN PEÁK, Hungary, Milan SeKanina, Czechoslovakia, and OtTó STEInFEld, Hungary. The names have never previously been published. Those in the picture are identified on the last page of this essay.

Many from the world-wide semigroup community contributed to this historical project, for which we should all be grateful. But for LEV SHEVRIN, it probably could not have been accomplished. He identified most of the attendees and supplied other photos he had received from A.H. CLIFFORD as proof of attendance of some of those 
not appearing in the group photo. Further, ŠTEFAN PORUBSKY was a major source of information. It was he who was given access to SCHWARZ's files and who graciously shared much information with me. JIRí SICHLER was very helpful in identifying a number of attendees and translated the BosÁK report for me. Contributions also came from Pavel Brunovsky, Goralcík, Hofmann, AnNa (SchWARZ) Hrabovská (Schwarz's daughter), KEIMEL, MÁrKI, and PETRICH.
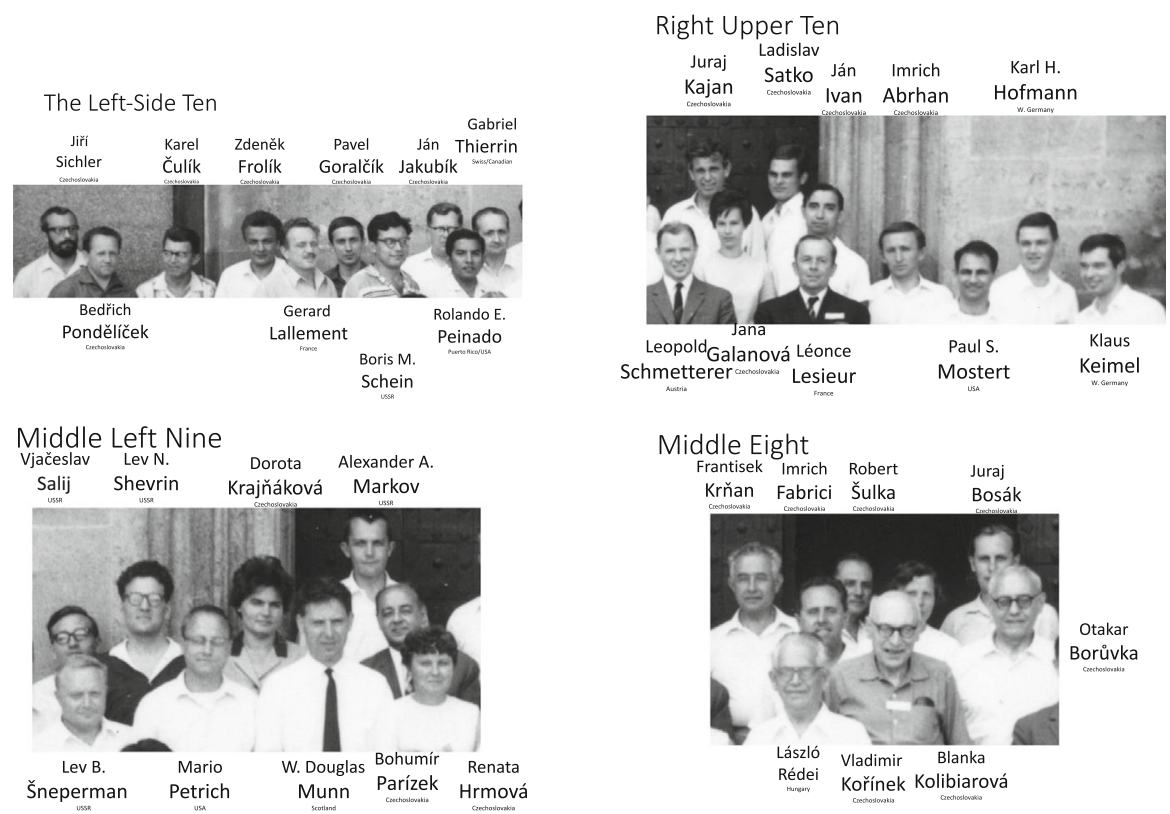

\section{The Front Row}

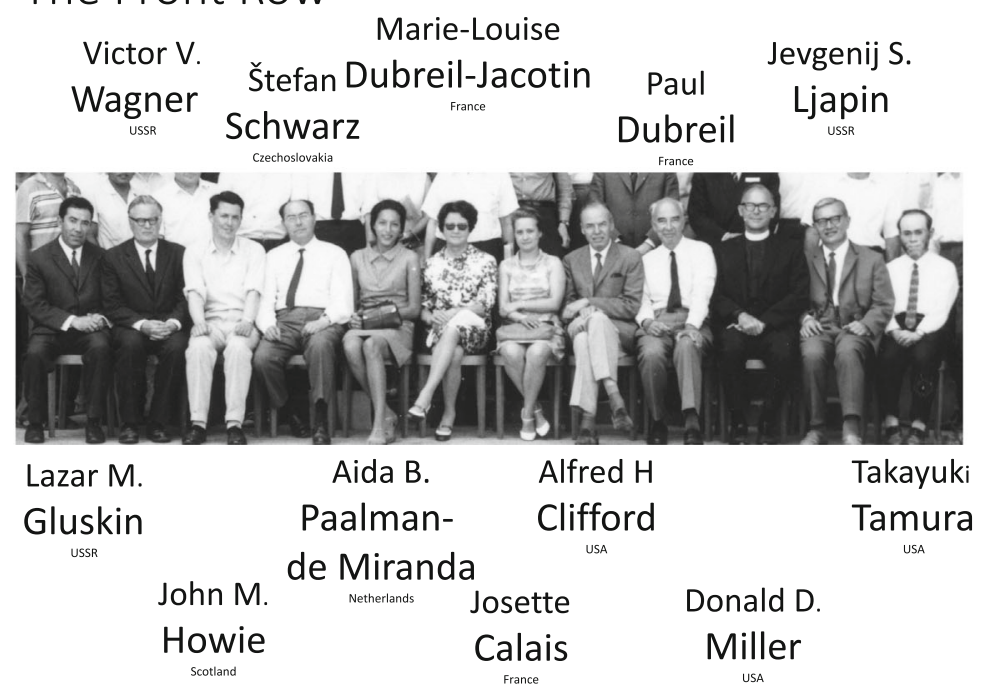




\section{References}

1. Bosák, J.: First International Symposium on Semigroup Theory. Mat. Časopis 18(4), 244-246 (1968) (in Slovak)

2. Lyapin, E.S., Shevrin, L.N.: International symposium on semigroup theory. Uspekhi Mat. Nauk. 24:3(147), 237-239 (1969) (in Russian)

3. Hofmann, K.H.: From a topological theory to a geometric one. Semigroup Forum 50, 123-134 (1995)

4. Hofmann, K.H., Mostert, P.S.: Elements of Compact Semigroups. Charles E. Merrill Books Inc., Columbus (1966)

Publisher's Note Springer Nature remains neutral with regard to jurisdictional claims in published maps and institutional affiliations. 